Original Research Paper

\title{
Mars Could have Enough Molecular Oxygen to Support Life
}

\author{
Relly Victoria Virgil Petrescu \\ ARoTMM-IFToMM, Bucharest Polytechnic University, Bucharest, (CE) Romania
}

Article history

Received: 16-02-2019

Revised: 23-02-2019

Accepted: 28-02-2019

Email: rvvpetrescu@gmail.com

\begin{abstract}
There is a recently introduced study that proposes the idea of the possibility of salty water somewhere on the surface of the planet Mars or immediately near the surface but in the basement of the planet at a relatively small depth. The study illustrates the possibility of $\mathrm{O}_{2}$ oxygen dissolved in salt water, oxygen needed to support breathing oxygen, microbes and complex organisms, such as sponges. "Nobody has actually thought of Mars as a place where aerobic breathing would work because there is enough oxygen in the atmosphere in the Earth," said Vlada Stamenkovic, a planetary scientist at the Jet Propulsion Laboratory who led the paper previously mentioned. "What we want to suggest is that it would be possible for this red planet that is so different from our Earth, although close, to have given a chance to aerobic life." As part of the report, Stamenkovic and his coauthors also wanted to identify the vast majority of Martian regions that could contain most of the salts with the highest amount of oxygen dissolved in them. This could help NASA and other space agencies to send out well-timed missions including the optimum place for amortization, they said. Planet Mars, as it now looks, is not what you consider to be a hospitable place for most earthlings. Here, on Earth, $21 \%$ of our atmosphere is made up of oxygen - because of the abundance of plants and other organisms that produce oxygen as a byproduct of photosynthesis. Once, the amount of oxygen was much higher on Earth, the percentage at that time being at least 28-30\%. The Martian atmosphere, on the other hand, is made up of $0.15 \%$ oxygen, according to data collected by specialists so far, so the chance that life will develop as on Earth with the current oxygen percentage is null. Without plants to produce $\mathrm{O}_{2}$, the small amount of oxygen on Mars is created when sunlight interacts with $\mathrm{CO}_{2}$ in the atmosphere of the planet. In addition, Mars' atmosphere is extremely thin - 160 times thinner than Earth's atmosphere. Such an atmosphere is not capable, as it is now to sustain life as we know it today on Earth. In addition, the surface temperature drops frequently to minus 100 degrees, making it extremely difficult to have liquid water on the surface of the planet. Liquid water will freeze or evaporate on Mars, but salty water or brine may remain liquid at or just beneath the surface of the planet, the authors said. This is due to the fact that the water mixed with salts has a lower frost temperature than the clean water.
\end{abstract}

Keywords: NASA, Water, Salt Water, Red Planet, Mars Lander, Mercury, Venus, Earth and Mars

\section{Introduction}

There is a recently introduced study that proposes the idea of the possibility of salty water somewhere on the surface of the planet Mars or immediately near the surface but in the basement of the planet at a relatively small depth. The study illustrates the possibility of $\mathrm{O}_{2}$ oxygen dissolved in salt water, oxygen needed to support breathing oxygen, microbes and complex organisms, such as sponges. "Nobody has actually thought of Mars as a place where aerobic breathing would work because there is enough oxygen 
in the atmosphere in the Earth," said Vlada Stamenkovic, a planetary scientist at the Jet Propulsion Laboratory who led the paper previously mentioned. "What we want to suggest is that it would be possible for this red planet that is so different from our Earth, although close, to have given a chance to aerobic life." As part of the report, Stamenkovic and his coauthors also wanted to identify the vast majority of Martian regions that could contain most of the salts with the highest amount of oxygen dissolved in them. This could help NASA and other space agencies to send out well-timed missions including the optimum place for amortization, they said. Planet Mars, as it now looks, is not what you consider to be a hospitable place for most earthlings. Here, on Earth, $21 \%$ of our atmosphere is made up of oxygen - because of the abundance of plants and other organisms that produce oxygen as a by-product of photosynthesis. Once, the amount of oxygen was much higher on Earth, the percentage at that time being at least $28-30 \%$. The Martian atmosphere, on the other hand, is made up of $0.15 \%$ oxygen, according to data collected by specialists so far, so the chance that life will develop as on Earth with the current oxygen percentage is null. Without plants to produce $\mathrm{O}_{2}$, the small amount of oxygen on Mars is created when sunlight interacts with $\mathrm{CO}_{2}$ in the atmosphere of the planet. In addition, Mars' atmosphere is extremely thin - 160 times thinner than Earth's atmosphere. Such an atmosphere is not capable, as it is now to sustain life as we know it today on Earth. In addition, the surface temperature drops frequently to minus 100 degrees, making it extremely difficult to have liquid water on the surface of the planet. Liquid water will freeze or evaporate on Mars, but salty water or brine may remain liquid at or just beneath the surface of the planet, the authors said. This is due to the fact that the water mixed with salts has a lower frost temperature than the clean water (Fig. 1).

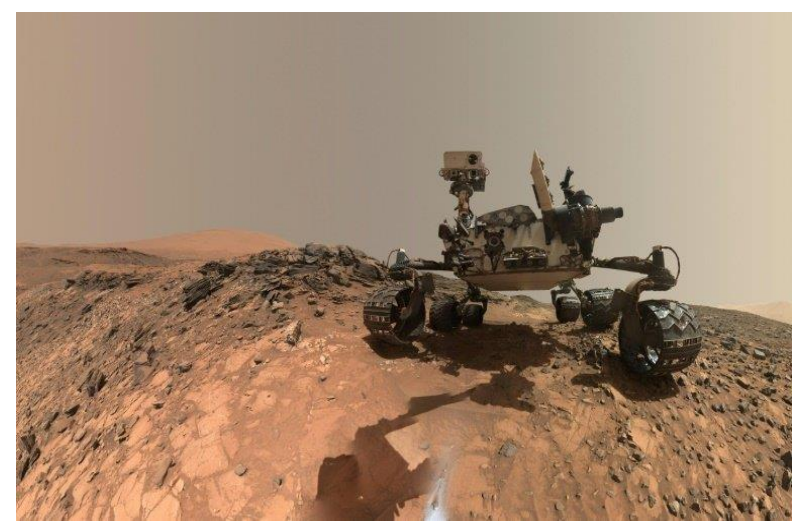

Fig. 1: The new research was made possible by the discovery by NASA's Curiosity Mars rover of manganese oxides
Once the authors were convinced that these liquid brines could exist, their next step was to determine how much-dissolved oxygen they could absorb from the atmosphere (Aversa et al., 2017a; 2017b; 2017c; 2017d; 2017e; 2016a; 2016b; 2016c; 2016d; 2016e; 2016f; 2016g; 2016h; 2016i; 2016j; 2016k; 2016l; 2016m; 2016n; 2016o; Mirsayar et al., 2017; Petrescu and Petrescu, 2013a; 2013b; 2013c; 2012; 2011; Petrescu, 2018, 2015a; 2015b, 2012; Petrescu et al., 2016a; 2016b; 2016c; 2017a; 2017b; 2017c; 2017d; 2017e; 2017f; 2017g; 2017h; 2017i; 2017j; 2017k; 2017l; 2018a; 2018b; 2018c; 2018d; Petrescu and Calautit, 2016a; 2016b; Daud et al., 2008; Taher et al., 2008; Zulkifli et al., 2008; Pourmahmoud, 2008; Pannirselvam et al., 2008; $\mathrm{Ng}$ et al., 2008; El-Tous, 2008; Akhesmeh et al., 2008; Nachiengtai et al., 2008; Moezi et al., 2008; Boucetta, 2008; Darabi et al., 2008; Semin and Bakar, 2008; Al-Abbas, 2009; Abdullah et al., 2009; Abu-Ein, 2009; Opafunso et al., 2009; Semin et al., 2009a; 2009b; 2009c; Zulkifli et al., 2009; Ab-Rahman et al., 2009; Abdullah and Halim, 2009; Zotos and Costopoulos, 2009; Feraga et al., 2009; Bakar et al., 2009; Cardu et al., 2009; Bolonkin, 2009a; 2009b; Nandhakumar et al., 2009; Odeh et al., 2009; Lubis et al., 2009; Fathallah and Bakar, 2009; Marghany and Hashim, 2009; Kwon et al., 2010; Aly and Abuelnasr, 2010; Farahani et al., 2010; Ahmed et al., 2010; Kunanoppadon, 2010; Helmy and El-Taweel, 2010; Qutbodin, 2010; Pattanasethanon, 2010; Fen et al., 2011; Thongwan et al., 2011; Theansuwan and Triratanasirichai, 2011; Al Smadi, 2011; Tourab et al., 2011; Raptis et al., 2011; Momani et al., 2011; Ismail et al., 2011; Anizan et al., 2011; Tsolakis and Raptis, 2011; Abdullah et al., 2011; Kechiche et al., 2011; Ho et al., 2011; Rajbhandari et al., 2011; Aleksic and Lovric, 2011; Kaewnai and Wongwises, 2011; Idarwazeh, 2011; Ebrahim et al., 2012; Abdelkrim et al., 2012; Mohan et al., 2012; Abam et al., 2012; Hassan et al., 2012; Jalil and Sampe, 2013; Jaoude and El-Tawil, 2013; Ali and Shumaker, 2013; Zhao, 2013; El-Labban et al., 2013; Djalel et al., 2013; Nahas and Kozaitis, 2014).

\section{Materials and Methods}

New data collected on Mars shows that Red Planet had at one point the ingredients necessary for the emergence of life. Curiosity found organic compounds on the surface of the planet after it dug only 5 centimeters deep into a crater. The area would once have been the bed of a lake, while Mars was not the kid we know now. In addition, the robot measured seasonal fluctuations in the methane concentration in the Martian atmosphere. On Earth, about $95 \%$ of methane comes from biological activities.

There are some of the strongest proofs so far that the neighboring planet could have sustained life. NASA scientists think it's too early to say. I say other non- 
biological explanations are possible for these discoveries, so the question of whether Martian life was alive is still unanswered.

"It is a significant advance because it shows that organic matter is preserved in the most difficult environments on Mars," said one of the studies published by Science magazine astrobiologist Jennifer Eigenbrode of Goddard Center for the US Space Agency.

Curiosity, which sat on Mars in 2012, has already discovered organic matter in small amounts in 2014.

"This study reveals in detail the discovery of complex and diversified organic compounds in sediments. This does not mean that there is life, but organic compounds are the basic bricks of life," said AFP and co-author of the study, Sanjeev Gupta, Professor of Earth Sciences at Imperial College London.

Samples of organic matter could come from a meteorite or geological formations equivalent to carbon or sedimentary rocks present on the Earth, or possibly any form of life, Eigenbrode said.

The Gale crater is a good place for a life form if it ever existed on Mars, she said.

The analysis in the French SAM (Sample Analysis at Mars) by the Curiosity robot revealed "several organic and volatile molecules that recall those found on Terra: Thiophene, methyl thiophene 2 and 3, methanethiol and dimethyl sulfide," study.

These findings tend to support the hypothesis of a potential existence of life on Mars, said Inge Loes ten Kate, from Tübingen University in Germany.

Images made from the orbit of the planet Mars Reconnaissance Orbiter (MRO) show the traces left by the water (photo), which in some cases are hundreds of meters long. These traces disappear in the cold months, but they reappear and stretch in the warmest. And chemical analyses confirm the existence of liquid water, the New York Times reported. It has been discovered with the use of a spectrometer the existence of salt molecules (perchlorates) soaked in liquid water. It is known that some perchlorates can prevent water from freezing even at temperatures of minus 70 degrees Celsius. On the surface of Mars, temperatures range between 20 degrees Celsius (noon and summer to the equator) and minus 153 degrees Celsius to the poles.

At average latitudes, average temperatures are minus 50 degrees Celsius and minus 60 degrees Celsius at night. In the summer, at noon, temperatures in these areas can reach a maximum of 0 degrees Celsius.

Researchers do not know where the water comes from, but it is likely to reach the surface from underground, aquifers, to be a result of condensation formed in the atmosphere. However, the humidity in the planet's atmosphere is very low. No precise measurements have been made near the surface of the planet. The aquifer is a geological formation represented by an underground layer quite porous of rocks so it can store water and sufficiently permeable that water can circulate freely through it. It is possible that these aquifers will freeze during the cold months on Mars and the summer will thaw.

"There is water today in liquid form on Martian surface," said Dr. Michael Meyer, the leader of NASA's Mars Exploration Program team, quoted by The Guardian.

The images overwhelmed by the MRO have attracted the attention of researchers since 2011, but they made the announcement of the existence of liquid water after they thoroughly analyzed and used a spectrometer.

Joe Michalski, a researcher at the Museum of Natural History in London, believes that the announcement made by NASA on Monday evening is especially interesting, especially due to its implications for the potential existence of colonies of microbes on Mars in the current period. "We know from the studies done on the extremophiles on Earth that life forms can not only survive, but also develop in abundance under conditions that are extremely arid, very saline, or in any other" extreme "environment in compared to people's habitat. In fact, on Terra, wherever we find water, we find life. This is why the discovery of water on Mars after research over 20 years is such an interesting matter, "said the British scientist.

These traces of water leakage can guide NASA and other organizations to areas where lifetimes are most likely to be discovered. Therefore, they will be landmarks for the future rover that will be sent to the planet. The currently accepted international rules state that space missions should be extremely careful about the locations on Mars where they want to place probes and robots and where there is probably liquid water. Peter Grindrod, a researcher at the British Space Agency, explained: "The principles of planetary protection stipulate that we cannot go anywhere there is liquid water because we cannot sterilize our spaceships well enough to ensure we do not contaminate those areas. So if an RSL (recurrent lines on the slopes - n.r.) is discovered in the rover placement area, then the rover cannot go down there. It's quite ironic, especially for the next European Space Agency, ExoMars, because it was designed to look for life forms."

A new rover, temporarily called Mars 2020, will go to Red Planet in five years. Curiosity, the rover on the planet since August 2012, has made several important discoveries since arriving on Mars, starting with finding evidence of an old waterbed and continuing with the detection of large methane emissions (an element that could be associated with life) and finding rocks formed in the presence of water.

Researchers knew that water was in the form of ice on Mars at the poles of the planet, but has not been discovered so far in liquid form (Fig. 2). 


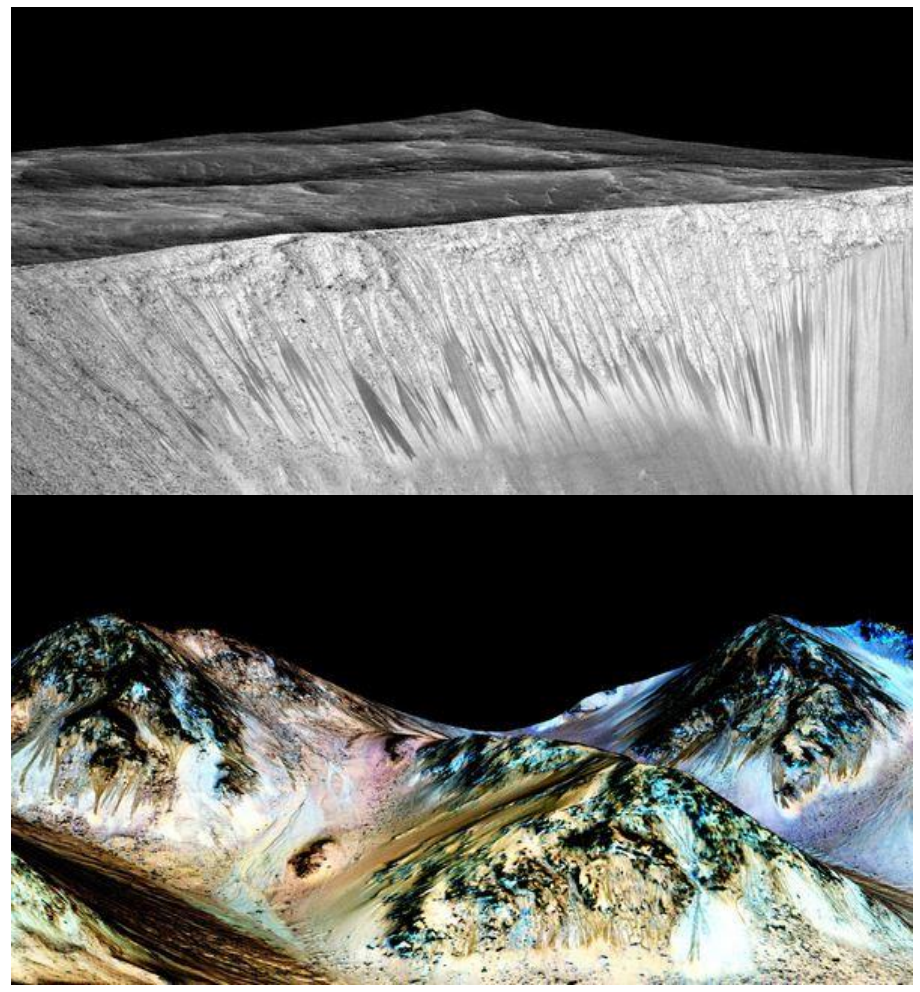

Fig. 2: Ice on the planet Mars discovered by NASA

In 1976, NASA's Viking landing probes reached Mars to answer one of the most important questions of humanity: "Is there life on the Red Planet?"

Gilbert Levin was the principal investigator of the Viking's Labeled Release (LR) life experiment. According to FoxNews, the tool has got a positive response in both places. But researchers have not reached a consensus on the accuracy of the results.

In 1977, Levin concluded that the experiment had found life on Mars. Currently, more than 40 years after the Viking probes, Levin believes that NASA has not properly mastered the results of Viking. "I'm sure NASA knows the existence of life on Mars," he said in July. The man urged the review of the data provided by Viking LR.

Over the course of the 40 years, several probes and rover would have collected information about life on Mars, says Levin. There is "subtle evidence of microbial life on the Red Planet," he said.

\section{Trace of Methane}

As an example, Levin said that NASA's Curiosity rover has found increases in methane, cyclic levels. More than $90 \%$ of the methane in the Earth's atmosphere is generated by microbes and organisms. But the chemical interaction between water and rocks can produce methane, so it cannot be considered clear evidence of life on Mars, scientists say.
Also, Curiosity has discovered organic molecules in rock sediments, 3 billion years old.

\section{The Water}

In July 2018, the Mars Express mission led by the European Space Agency provided information on the existence of a subterranean lake at the southern pole of the planet. Several wells have discovered water on Mars, Levin said, so "water is no longer a problem."

Levin added that the images provided by Curiosity could depict stromatolites, structures built by microbes on Earth. Everything I learned about sedimentary rocks on Mars, says Levin, shows that Earth's microorganisms can survive, including powerful radiation, low pressure, or low temperatures.

\section{More Evidence}

One of the veterans of the Viking mission, currently a researcher at the Space Science Institute in Boulder, Colorado, says "it is time to seriously treat the search for life on Mars." Clark developed a tool that measures the composition of Martian soil.

"As far as we know from the Viking mission, Mars is more suitable for the development of life than we previously thought.

But astrobiologist Dirk Schulze-Makuch said that any statement about life on Mars requires an important set of evidence to be supported. 
Once the authors seemed convinced that these liquid salts might exist on the red planet, the next step was to figure out how much-dissolved oxygen can be absorbed from the atmosphere.

"If there are salts on Mars, then oxygen would have no choice but to infiltrate," said Woody Fischer, a Caltech geobiologist who also participated in this study.

To calculate the amount of oxygen that could be absorbed by salt, the researchers had to consider their chemistry as well as the temperature and air pressure on the Martian surface. The soil will absorb more oxygen when the temperature is lower and the air pressure is higher.

The results of these calculations have shown that Mars could support liquid media with enough dissolved $\mathrm{O}_{2}$ to support microbes that inspire oxygen on the planet. It was also found that oxygen concentrations would be particularly high in brine, which is found in the polar regions where the temperatures are colder.

So far, this work has been done by computer modeling. However, most experts say the study seems robust.

"The best model-based studies for their results lead to an in-depth analysis of the possible variables that can influence model production," said Kathleen Mandt, a biologist at Johns Hopkins Applied Physics Laboratory. This study does a good job of exploring a number of possible outcomes."

What was not caused by this study, however, is that there are truly salty salts on Mars.

"What we know is that, theoretically, they should be salted on Mars and that they will be able to dissolve enough oxygen to be biologically useful," Stamenkovic said.

The next step, he said, is to seek, to experience and learn.

He hopes that the Earth scientists will do experiments to put microbes that breathe oxygen into the cheese salts that might appear on Mars to find out what kind of chemistry they are doing and whether they can thrive. The other step would be to send a lander to Mars, looking for salt from deep to deep.

"An amazing work has been done by NASA to look for evidence of habitable habits in the past," he said. "I am a great promoter in search of current living environments and we can do that by exploring whether there is liquid water on Mars."

To that end, Stamenkovic is working to develop a new tool, no bigger than a shoe box, that could be used to find water on Mars and determine its salinity, no digging necessary (Netburn, 2018).

\section{Results}

The first natural question that people ask when it comes to the red planet is can it live on Mars? Was there ever live there? The population of our planet has far exceeded the boundaries from which the planet begins to overwhelm. Global resources are falling sharply, while their consumption is rising more and more. The population of the planet is steadily increasing with all the measures taken to diminish this growth and even if it has not been exponential, continued growth is still significant, so it is natural to ask ourselves when we start exploring our system solar to try to ground some of the closest planets. The world is growing, it needs housing, food, water, air, clothes, transport, energy and the possibilities offered by our planet are getting smaller. Since we have long gone through the chapter on "conquering space", we seriously consider limiting existing resources for current and future populations as well as for those wishing to expand into desert waters or desert areas. In order to be able to conquer the cosmic space with today's highly evolving technologies, a huge financial effort is needed, but unfortunately, the current financial support is not at the level of necessity. Under these circumstances, it is natural to ask whether there is a possibility to live on Mars, which is a subject of great interest for astrobiology due to the proximity of the planet and its similarities to the Earth. So far, no concrete evidence has been found about past or present life on Mars, but the evidence now proves that during the ancient nightlife, the surface of the planet had liquid water and could be useful for microorganisms. On the other hand, the existence of living conditions itself does not necessarily imply the presence of life.

The scientific research needed to prove whether or not there was life on the red planet began in the nineteenth century and continues today through telescopic investigations and landings. If early studies focused on phenomenology and confined to fantasy, modern scientific research has highlighted the search for atmospheric water, soil biosignatures, surface biosensors and biomarkers. On November 22, 2016, NASA reported that it found a large amount of underground ice in the Utopia Planet area of Mars. The volume of water detected was estimated to be equivalent to the volume of water in the Upper Lake, a large amount of water.

Mars is a special interest in studying the origins of life because of its similarity to Early Earth. This is especially true because Mars has a cold climate and does not have a tectonic plate or a drifting continent, which has kept it almost unchanged since the end of the Hesperian period. We think that at least two-thirds of Mars's surface is 3.5 billion years and Mars can have the best data on prebiotic conditions that lead to abiogenesis, even if life does not exist or has never been there. In May 2017, evidence of the oldest known life on Earth is found in the 3.39 billion-year geyser and other mineral deposits (mostly located around springs and ice) found in Craton Pilbara, Western Australia. Such newly discovered evidence could be useful in deciding where to look for the best signs of water, oxygen, life on Mars. 
On January 24, 2014, NASA reported that its Mars probes have begun to look for evidence of past life, including a biotope based on autotrophic microorganisms, autotrophic chemotrophic chemotrophy and old water (as recently found on Terra in Australian waters and lakes) in the Martian areas that could have been inhabited. More recently, searching for evidence of habitats, taphonomy (related to fossils) and organic carbon on Mars is now a major objective of NASA.

In July 2017, researchers showed that the surface of Mars could be more toxic to microorganisms, especially for a common type of Bacillus subtilis, as they initially thought, based on Mars perchlorinated studies in an ultraviolet martian.

On September 5, 2017, scientists reported that Mars Curiosity Rover detected on the surface of the red planet the existence of boron, an essential ingredient for life on Earth. Such a discovery, along with previous discoveries of the fact that liquid water was clearly present on the ancient Mars, still supports the possible adaptation of Mars to life, starting from already existing elements that naturally support life on a planet, at least life as we know it today.

ExoMars (Mars Exobiology) is a two-part astrobiology project to look for martial arts, a joint mission of the European Space Agency (ESA) and the Rosice Space Agency. The first part of the project, launched in 2016, placed a research and communication satellite on Mars orbit and launched an experimental landing vehicle (which collapsed). The second part of the project is planned for 2020, when a rover will be launched and landed on the surface of Mars, sustaining a scientific mission that is expected to last until 2022 or even later.

The major objectives of the ExoMars programs are to look for previous signs of life on Mars, to begin a major investigation into Martian waters and the red planet's geochemical environments, as studies on atmospheric gases and sources vary greatly. He will search for the old bio-signs in Martian life using some elements of the spacecraft that will be sent to Mars in two launches.

The ExoMars Trace Gas Examiners (TGO) and a stationary testator named Schiaparelli was launched on March 14, 2016. TGO entered Mars' orbit on October 19, 2016 and will continue to capture methane $\left(\mathrm{CH}_{4}\right)$ and other gas pathways present in the Martian atmosphere which could be a proof of possible biological or geological activity. TGO has four instruments and will function as a communications retransmission satellite. The Schiaparelli experimental space was separated from TGO on October 16 and was maneuvered to land in Meridiani Planum, but unfortunately collapsed on the surface of Mars. The landing was designed to test new key technologies to safely deliver the rover 2020 mission.
In 2020, a platform built by Roscosmos (ExoMars 2020 platform) will have to deliver an ExoMars Rover built by ESA on the Martian surface. The rover will include several tools built by Roscosmos. The two missions and communications operations will be run by the Rover ALTEC control center (ExoMars, from Wikipedia).

Ever since it was first designed, the ExoMars program has gone through several planning stages, including various proposals for landing, orbiting, launching and planning international cooperation, such as the Mars Exploration 2009 Joint Initiative (MEJI) with the United States. The ExoMars concept initially consisted only of a robust large-scale system that is part of ESA's Aurora program as a prime mission and was endorsed by the Ministries of the European Space Agency in December 2005. It was originally conceived as a rover vehicle stationed in 2011 aboard a Russian rocket Soyuz Fregat.

In fact, we can say that the ExoMars project began in 2001 as part of the ESA Aurora program for human exploration of the planet Mars. This initial vision later turned to a rover in 2009 and later on a return mission. Another mission to support the Aurora program is an idea to return to Phobos. In December 2005, the various ESA States approved both the Aurora program and the ExoMars project. Aurora being an optional program, each state has the right to decide which part of the program it wants to be involved and to what extent (for example, how many funds can be put into the program, or with what technologies each state will contribute so that the program does not it is already finalized, but leaves it to the participating states to actually finalize it later, some of the advantages of many of them turn into disadvantages because things are not clearly established from the very beginning, especially in the participation of each state, in components, technologies, financing etc.). The Aurora program was launched in 2002 with the support of twelve countries: Austria, Belgium, France, Germany, Italy, the Netherlands, Portugal, Spain, Sweden, Switzerland, the United Kingdom and Canada. Even though it was not a simple and clear one like the American one, it still has the merit of being.

\section{Discussion}

In 2007, Macdonald Dettwiler and Associates Ltd. (MDA) was selected through a EUR 1 million contract with EADS Astrium in the UK to design and build a prototype chassis for the Martian rotor used by the European Space Agency. Astrium was also contracted to realize the final project of a Martian rover.

In July 2009, NASA and ESA took an important step in this direction by signing Joint Exploration Mars, which proposed the use of an Atlas rocket launcher instead of the Soyuz type, which led to a significant 
change in all technical and financial settings belonging to of the entire ExoMars mission. So on June 19, when Mars Trace Gas Orbiter was launched, it was reported that a prospective agreement would force ExoMars to lose much of its weight in order to fit the board of the vehicle to be launched (Atlas with an orbiter NASA). Thus, international space collaboration issues have greatly complicated existing programs but have led to some optimizations that could be extremely useful for future missions. In addition, this mission was combined with other projects resulting in a multi-spatial mission divided into two Atlas V launches. On this occasion, the ExoMars Trace Gas Orbiter project (TGO) was also integrated into the project with a meteor landing launched in January 2016. In addition, it was proposed to include a second rover, MAX-C.

In August 2009, the Russian Federal Space Agency (Roscosmos) and ESA signed an important contract, including cooperation in two major Mars exploration projects: The Phobos-Grunt project of Russia and ExoMars belonging to ESA. ESA has thus secured the support of a Russian missile, which will be a "reserve launcher" for the ExoMars rover and will also include other components manufactured in Russia.

On December 17, 2009, all governments involved in the AES agreed on a mission to explore the planet Mars, a mission that can be carried out together with NASA, thus confirming their joint commitment to spend 850 million euros on missions in 2016 and 2018.

Unfortunately, however, these joint missions often have more deficiencies than advantages and so it happened even when two years later, in April 2011, due to a budget crisis, the proposal to cancel the MAX-C and decided to fly with a single rover in 2018, claiming it would be larger than any of the vehicles in the associated concept.

In addition, there is a suggestion that the new vehicle will be built in Europe but will have a mix of European and American instruments. NASA would provide rocket systems capable of transmitting them to Mars, as well as the crane landing system.

Despite the drastic reorganization, it has been suggested that the major objectives of the 2018 mission remain unchanged in order not to disrupt the important global program, despite some delays or changes that have already occurred due to international participation in the program.

But unfortunately, a new blow is being announced for this important international space program for the future of mankind thanks to the US budget in 2013 developed and approved by President Obama as early as February 13, 2012 when NASA changed its mind and ceased participating in the ExoMars program actually due to budget cuts that were intended to pay the telescope cost surplus, James Webb.
Thus, the project's situation has become dramatic, especially financially and technically and NASA's total loss of US funding (for this completely canceled project), so the US will no longer be able to support the project itself and nor will it be able to honor the contracts originally signed simply because of lack of funding, so the initial project will have to undergo major changes in order not to succumb and most of these plans have to be restructured again significantly this time without NASA and without the American side.

Due to the fact that US support was completely withdrawn by US President Obama on March 14, 2013, a meeting with representatives of ESA in emergency situations and Russia's Roscosmos Agency was signed and an agreement was signed by which Russia became the full partner of the project). Roscosmos will now deliver Briton-M services and also launch Proton launch services for both missions as well as an additional landing, landing on the red planet (which was otherwise specific to NASA specialists, now government shortcuts) and landing for the rover mission in 2018. Under the new agreement, Roscosmos has three necessary conditions:

Roscosmos will contribute with two Proton launchers as a partnership.

Trace Gas Traffic Orbiter will include two Russian instruments that were originally developed for Phobos-Grunt.

All scientific results must be the intellectual property of the European Space Agency and the Russian Academy of Sciences (for example, Roscosmos will also have full access to research data, completely replacing NASA specialists in this extremely important international program).

\section{Conclusion}

There is a recently introduced study that proposes the idea of the possibility of salty water somewhere on the surface of the planet Mars or immediately near the surface but in the basement of the planet at a relatively small depth.

The study illustrates the possibility of $\mathrm{O}_{2}$ oxygen dissolved in salt water, oxygen needed to support breathing oxygen, microbes and complex organisms, such as sponges. "Nobody has actually thought of Mars as a place where aerobic breathing would work because there is enough oxygen in the atmosphere in the Earth," said Vlada Stamenkovic, a planetary scientist at the Jet Propulsion Laboratory who led the paper previously mentioned. "What we want to suggest is that it would be possible for this red planet that is so different from our Earth, although close, to have given a chance to aerobic life."

As part of the report, Stamenkovic and his coauthors also wanted to identify the vast majority of Martian 
regions that could contain most of the salts with the highest amount of oxygen dissolved in them.

This could help NASA and other space agencies to send out well-timed missions including the optimum place for amortization, they said. Planet Mars, as it now looks, is not what you consider to be a hospitable place for most earthlings.

Here, on Earth, $21 \%$ of our atmosphere is made up of oxygen - because of the abundance of plants and other organisms that produce oxygen as a by-product of photosynthesis. Once, the amount of oxygen was much higher on Earth, the percentage at that time being at least 28-30\%.

The Martian atmosphere, on the other hand, is made up of $0.15 \%$ oxygen, according to data collected by specialists so far, so the chance that life will develop as on Earth with the current oxygen percentage is null. Without plants to produce $\mathrm{O}_{2}$, the small amount of oxygen on Mars is created when sunlight interacts with $\mathrm{CO}_{2}$ in the atmosphere of the planet. In addition, Mars' atmosphere is extremely thin - 160 times thinner than Earth's atmosphere. Such an atmosphere is not capable, as it is now to sustain life as we know it today on Earth. In addition, the surface temperature drops frequently to minus 100 degrees, making it extremely difficult to have liquid water on the surface of the planet. Liquid water will freeze or evaporate on Mars, but salty water or brine may remain liquid at or just beneath the surface of the planet, the authors said. This is due to the fact that the water mixed with salts has a lower frost temperature than the clean water.

\section{Acknowledgement}

The work was appreciated by teams of professors from the departments of automobiles from several universities in Romania and Italy. This text was acknowledged and appreciated by Associate Professor Aniello Riccio SECONDA UNIVERSITA’ DEGLI STUDI DI NAPOLI Italy, whom we thanks and in this way.

\section{Funding Information}

Research contract: Contract number 36-5-4D/1986 from 24IV1985, beneficiary CNST RO (Romanian National Center for Science and Technology) Improving dynamic mechanisms internal combustion engines. All these matters are copyrighted. Copyrights: 548cgiywDssin, from: 22-04-2010, 08:48:48.

\section{Ethics}

Author declares that are not ethical issues that may arise after the publication of this manuscript. This article is original and contains unpublished material.

\section{References}

Ab-Rahman, M.S., H. Guna, MH. Harun, SD. Zan and K. Jumari, 2009. Cost-effective fabrication of selfmade $1 \times 12$ polymer optical fiber-based optical splitters for automotive application. Am. J. Eng. Applied Sci., 2: 252-259.

DOI: 10.3844/ajeassp.2009.252.259

Abam, F.I., I.U. Ugot and D.I. Igbong, 2012. Performance analysis and components irreversibilities of a $(25 \mathrm{MW})$ gas turbine power plant modeled with a spray cooler. Am. J. Eng. Applied Sci., 5: 35-41.

DOI: 10.3844/ajeassp.2012.35.41

Abdullah, M.Z., A. Saat and Z. Hamzah, 2011. Optimization of energy dispersive $\mathrm{x}$-ray fluorescence spectrometer to analyze heavy metals in moss samples. Am. J. Eng. Applied Sci., 4: 355-362. DOI: 10.3844/ajeassp.2011.355.362

Abdullah, M., A. F.M. Zain, Y. H. Ho and S. Abdullah, 2009. TEC and scintillation study of equatorial ionosphere: A month campaign over sipitang and parit raja stations, Malaysia. Am. J. Eng. Applied Sci., 2: 44-49. DOI: 10.3844/ajeassp.2009.44.49

Abdullah, H. and S.A. Halim, 2009. Electrical and magnetoresistive studies $\mathrm{Nd}$ doped on La-Ba-Mn- $\mathrm{O}_{3}$ manganites for low-field sensor application. Am. J. Eng. Applied Sci., 2: 297-303.

DOI: 10.3844/ajeassp.2009.297.303

Abu-Ein, S., 2009. Numerical and analytical study of exhaust gases flow in porous media with applications to diesel particulate filters. Am. J. Eng. Applied Sci., 2: 70-75. DOI: 10.3844/ajeassp.2009.70.75

Ahmed, M., R. Khan, M. Billah and S. Farhana, 2010. A novel navigation algorithm for hexagonal hexapod robot. Am. J. Eng. Applied Sci., 3: 320-327. DOI: 10.3844/ajeassp.2010.320.327

Akhesmeh, S., N. Pourmahmoud and H. Sedgi, 2008. Numerical study of the temperature separation in the ranque-hilsch vortex tube. Am. J. Eng. Applied Sci., 1: 181-187. DOI: 10.3844/ajeassp.2008.181.187

Al-Abbas, I.K., 2009. Reduced order models of a current source inverter induction motor drive. Am. J. Eng. Applied Sci., 2: 39-43. DOI: 10.3844 /ajeassp.2009.39.43

Al Smadi, T.A., 2011. Low cost smart sensor design. Am. J. Eng. Applied Sci., 4: 162-168.

DOI: 10.3844/ajeassp.2011.162.168

Aleksic, S. and A. Lovric, 2011. Energy consumption and environmental implications of wired access networks. Am. J. Eng. Applied Sci., 4: 531-539. DOI: 10.3844/ajeassp.2011.531.539

Ali, K.S. and J.L. Shumaker, 2013. Hardware in the loop simulator for multi-agent unmanned aerial vehicles environment. Am. J. Eng. Applied Sci., 6: 172-177. DOI: 10.3844/ajeassp.2013.172.177 
Aly, W.M. and M.S. Abuelnasr, 2010. Electronic design automation using object oriented electronics. Am. J. Eng. Applied Sci., 3: 121-127.

DOI: 10.3844/ajeassp.2010.121.127

Anizan, S., K. Yusri, C.S. Leong, N. Amin and S. Zaidi et al., 2011. Effects of the contact resistivity variations of the screen-printed silicon solar cell. Am. J. Eng. Applied Sci., 4: 328-331. DOI: 10.3844/ajeassp.2011.328.331

Aversa, R., R.V.V. Petrescu, A. Apicella and F.I.T. Petrescu, 2017a. Nano-diamond hybrid materials for structural biomedical application. Am. J. Biochem. Biotechnol., 13: 34-41.

DOI: 10.3844/ajbbsp.2017.34.41

Aversa, R., R.V. Petrescu, B. Akash, R.B. Bucinell and J.M. Corchado et al., 2017b. Kinematics and forces to a new model forging manipulator. Am. J. Applied Sci., 14: 60-80. DOI: 10.3844/ajassp.2017.60.80

Aversa, R., R.V. Petrescu, A. Apicella, I.T.F. Petrescu and J.K. Calautit et al., 2017c. Something about the $\mathrm{V}$ engines design. Am. J. Applied Sci., 14: 34-52. DOI: 10.3844/ajassp.2017.34.52

Aversa, R., D. Parcesepe, R.V.V. Petrescu, F. Berto and G. Chen et al., 2017d. Process ability of bulk metallic glasses. Am. J. Applied Sci., 14: 294-301. DOI: 10.3844/ajassp.2017.294.301

Aversa, R., R.V.V. Petrescu, B. Akash, R.B. Bucinell and J.M. Corchado et al., 2017e. Something about the balancing of thermal motors. Am. J. Eng. Applied Sci., 10: 200.217.

DOI: 10.3844/ajeassp.2017.200.217

Aversa, R., F.I.T. Petrescu, R.V. Petrescu and A. Apicella, 2016a. Biomimetic FEA bone modeling for customized hybrid biological prostheses development. Am. J. Applied Sci., 13: 1060-1067. DOI: 10.3844/ajassp.2016.1060.1067

Aversa, R., D. Parcesepe, R.V. Petrescu, G. Chen and F.I.T. Petrescu et al., 2016b. Glassy amorphous metal injection molded induced morphological defects. Am. J. Applied Sci., 13: 1476-1482.

DOI: 10.3844/ajassp.2016.1476.1482

Aversa, R., R.V. Petrescu, F.I.T. Petrescu and A. Apicella, 2016c. Smart-factory: Optimization and process control of composite centrifuged pipes. Am. J. Applied Sci., 13: 1330-1341.

DOI: 10.3844 /ajassp.2016.1330.1341

Aversa, R., F. Tamburrino, R.V. Petrescu, F.I.T. Petrescu and M. Artur et al., 2016d. Biomechanically inspired shape memory effect machines driven by muscle like acting NiTi alloys. Am. J. Applied Sci., 13: 1264-1271. DOI: 10.3844/ajassp.2016.1264.1271

Aversa, R., E.M. Buzea, R.V. Petrescu, A. Apicella and M. Neacsa et al., 2016e. Present a mechatronic system having able to determine the concentration of carotenoids. Am. J. Eng. Applied Sci., 9: 1106-1111. DOI: 10.3844/ajeassp.2016.1106.1111
Aversa, R., R.V. Petrescu, R. Sorrentino, F.I.T. Petrescu and A. Apicella, 2016f. Hybrid ceramo-polymeric nanocomposite for biomimetic scaffolds design and preparation. Am. J. Eng. Applied Sci., 9: 1096-1105. DOI: 10.3844/ajeassp.2016.1096.1105

Aversa, R., V. Perrotta, R.V. Petrescu, C. Misiano and F.I.T. Petrescu et al., 2016g. From structural colors to super-hydrophobicity and achromatic transparent protective coatings: Ion plating plasma assisted $\mathrm{TiO}_{2}$ and $\mathrm{SiO}_{2}$ Nano-film deposition. Am. J. Eng. Applied Sci., 9: 1037-1045.

DOI: 10.3844/ajeassp.2016.1037.1045

Aversa, R., R.V. Petrescu, F.I.T. Petrescu and A. Apicella, 2016h. Biomimetic and Evolutionary Design Driven Innovation in Sustainable Products Development, Am. J. Eng. Applied Sci., 9: 1027-1036. DOI: 10.3844/ajeassp.2016.1027.1036

Aversa, R., R.V. Petrescu, A. Apicella and F.I.T. Petrescu, 2016i. Mitochondria are naturally micro robots-a review. Am. J. Eng. Applied Sci., 9: 9911002. DOI: 10.3844/ajeassp.2016.991.1002

Aversa, R., R.V. Petrescu, A. Apicella and F.I.T. Petrescu, 2016j. We are addicted to vitamins $\mathrm{C}$ and E-A review. Am. J. Eng. Applied Sci., 9: 1003-1018.

DOI: 10.3844/ajeassp.2016.1003.1018

Aversa, R., R.V. Petrescu, A. Apicella and F.I.T. Petrescu, 2016k. Physiologic human fluids and swelling behavior of hydrophilic biocompatible hybrid ceramo-polymeric materials. Am. J. Eng. Applied Sci., 9: 962-972.

DOI: 10.3844/ajeassp.2016.962.972

Aversa, R., R.V. Petrescu, A. Apicella and F.I.T. Petrescu, 20161. One can slow down the aging through antioxidants. Am. J. Eng. Applied Sci., 9: 1112-1126.

DOI: 10.3844/ajeassp.2016.1112.1126

Aversa, R., R.V. Petrescu, A. Apicella and F.I.T. Petrescu, 2016m. About homeopathy or «Similia similibus curentur $\gg$. Am. J. Eng. Applied Sci., 9: 1164-1172. DOI: 10.3844/ajeassp.2016.1164.1172

Aversa, R., R.V. Petrescu, A. Apicella and F.I.T. Petrescu, 2016n. The basic elements of life's. Am. J. Eng. Applied Sci., 9: 1189-1197.

DOI: 10.3844/ajeassp.2016.1189.1197

Aversa, R., F.I.T. Petrescu, R.V. Petrescu and A. Apicella, 2016o. Flexible stem trabecular prostheses. Am. J. Eng. Applied Sci., 9: 1213-1221. DOI: 10.3844/ajeassp.2016.1213.1221

Bakar, R.A., M.K. Mohammed and M.M. Rahman, 2009. Numerical study on the performance characteristics of hydrogen fueled port injection internal combustion engine, Am. J. Eng. Applied Sci., 2: 407-415. DOI: 10.3844/ajeassp.2009.407.415 
Bolonkin, A., 2009a. Femtotechnology: Nuclear matter with fantastic properties. Am. J. Eng. Applied Sci., 2: 501-514.

DOI: 10.3844/ajeassp.2009.501.514

Bolonkin, A., 2009b. Converting of matter to nuclear energy by ab-generator. Am. J. Eng. Applied Sci., 2: 683-693. DOI: 10.3844/ajeassp.2009.683.693

Boucetta, A., 2008. Vector control of a variable reluctance machine stator and rotor discs imbricates. Am. J. Eng. Applied Sci., 1: 260-265.

DOI: 10.3844/ajeassp.2008.260.265

Cardu, M., P. Oreste and T. Cicala, 2009. Analysis of the tunnel boring machine advancement on the bolognaflorence railway link. Am. J. Eng. Applied Sci., 2: 416-420. DOI: 10.3844/ajeassp.2009.416.420

Darabi, A., S.A. Soleamani and A. Hassannia, 2008. Fuzzy based digital automatic voltage regulator of a synchronous generator with unbalanced loads. Am. J. Eng. Applied Sci., 1: 280-286. DOI: 10.3844/ajeassp.2008.280.286

Daud, H., N. Yahya, A.A. Aziz and M.F. Jusoh, 2008. Development of wireless electric concept powering electrical appliances. Am. J. Eng. Applied Sci., 1: 12-15. DOI: 10.3844/ajeassp.2008.12.15

Djalel, D., M. Mourad and H. Labar, 2013. New approach of electromagnetic fields of the lightning discharge. Am. J. Eng. Applied Sci., 6: 369-383. DOI: 10.3844/ajeassp.2013.369.383

Ebrahim, N.A., S. Ahmed, S.H.A. Rashid and Z. Taha, 2012. Technology use in the virtual R\&D teams. Am. J. Eng. Applied Sci., 5: 9-14.

DOI: 10.3844/ajeassp.2012.9.14

El-Labban, H.F., M. Abdelaziz and E.R.I. Mahmoud, 2013. Modification of carbon steel by laser surface melting: Part I: Effect of laser beam travelling speed on microstructural features and surface hardness. Am. J. Eng. Applied Sci., 6: 352-359.

DOI: 10.3844/ajeassp.2013.352.359

El-Tous, Y., 2008. Pitch angle control of variable speed wind turbine. Am. J. Eng. Applied Sci., 1: 118-120. DOI: 10.3844/ajeassp.2008.118.120

Farahani, A.S., N.M. Adam and M.K.A. Ariffin, 2010. Simulation of airflow and aerodynamic forces acting on a rotating turbine ventilator. Am. J. Eng. Applied Sci., 3: 159-170.

DOI: 10.3844/ajeassp.2010.159.170

Fathallah, A.Z.M. and R.A. Bakar, 2009. Prediction studies for the performance of a single cylinder high speed spark ignition linier engine with spring mechanism as return cycle. Am. J. Eng. Applied Sci., 2: 713-720.

DOI: 10.3844/ajeassp.2009.713.720

Fen, Y.W., W.M.M. Yunus, M.M. Moksin, Z.A. Talib and N.A. Yusof, 2011. Optical properties of crosslinked chitosan thin film with glutaraldehyde using surface plasmon resonance technique. Am. J. Eng. Applied Sci., 4: 61-65.

DOI: 10.3844/ajeassp.2011.61.65

Feraga, C.E., A. Moussaoui, A. Bouldjedri and A. Yousfi, 2009. Robust position controller for a permanent magnet synchronous actuator. Am. J. Eng. Applied Sci., 2: 388-392.

DOI: 10.3844/ajeassp.2009.388.392

Hassan, M., H. Mahjoub and M. Obed, 2012. Voicebased control of a DC servo motor. Am. J. Eng. Applied Sci., 5: 89-92.

DOI: 10.3844 /ajeassp.2012.89.92

Helmy, A.K. and G.S. El-Taweel, 2010. Neural network change detection model for satellite images using textural and spectral characteristics. Am. J. Eng. Applied Sci., 3: 604-610.

DOI: $10.3844 /$ ajeassp.2010.604.610

Ho, C.Y.F., B.W.K. Ling, S.G. Blasi, Z.W. Chi and W.C. Siu, 2011. Single step optimal block matched motion estimation with motion vectors having arbitrary pixel precisions. Am. J. Eng. Applied Sci., 4: 448-460. DOI: 10.3844/ajeassp.2011.448.460

Idarwazeh, S., 2011. Inverse discrete Fourier transform-discrete Fourier transform techniques for generating and receiving spectrally efficient frequency division multiplexing signals. Am. J. Eng. Applied Sci., 4: 598-606.

DOI: $10.3844 /$ ajeassp.2011.598.606

Ismail, M.I.S., Y. Okamoto, A. Okada and Y. Uno, 2011. Experimental investigation on micro-welding of thin stainless steel sheet by fiber laser. Am. J. Eng. Applied Sci., 4: 314-320.

DOI: 10.3844/ajeassp.2011.314.320

Jalil, M.I.A. and J. Sampe, 2013. Experimental investigation of thermoelectric generator modules with different technique of cooling system. Am. J. Eng. Applied Sci., 6: 1-7. DOI: 10.3844/ajeassp.2013.1.7

Jaoude, A.A. and K. El-Tawil, 2013. Analytic and nonlinear prognostic for vehicle suspension systems. Am. J. Eng. Applied Sci., 6: 42-56.

DOI: 10.3844 /ajeassp.2013.42.56

Kaewnai, S. and S. Wongwises, 2011. Improvement of the runner design of francis turbine using computational fluid dynamics. Am. J. Eng. Applied Sci., 4: 540-547. DOI: 10.3844/ajeassp.2011.540.547

Kechiche, O.B.H.B., H.B.A. Sethom, H. Sammoud and I.S. Belkhodja, 2011. Optimized high-frequency signal injection based permanent magnet synchronous motor rotor position estimation applied to washing machines. Am. J. Eng. Applied Sci., 4: 390-399. DOI: 10.3844/ajeassp.2011.390.399

Kunanoppadon, J., 2010. Thermal efficiency of a combined turbocharger set with gasoline engine. Am. J. Eng. Applied Sci., 3: 342-349.

DOI: 10.3844/ajeassp.2010.342.349 
Kwon, S., Y. Tani, H. Okubo and T. Shimomura, 2010. Fixed-star tracking attitude control of spacecraft using single-gimbal control moment gyros. Am. J. Eng. Applied Sci., 3: 49-55.

DOI: 10.3844 /ajeassp.2010.49.55

Lubis, Z., A.N. Abdalla, Mortaza and R. Ghon, 2009. Mathematical modeling of the three phase induction motor couple to DC motor in hybrid electric vehicle. Am. J. Eng. Applied Sci., 2: 708-712.

DOI: 10.3844/ajeassp.2009.708.712

Marghany, M. and M. Hashim, 2009. Robust of doppler centroid for mapping sea surface current by using radar satellite data. Am. J. Eng. Applied Sci., 2: 781-788. DOI: 10.3844/ajeassp.2009.781.788

Mirsayar, M.M., V.A. Joneidi, R.V.V. Petrescu, F.I.T. Petrescu and F. Berto, 2017. Extended MTSN criterion for fracture analysis of soda lime glass. Eng. Fracture Mechan., 178: 50-59.

DOI: 10.1016/j.engfracmech.2017.04.018

Moezi, N., D. Dideban and A. Ketabi, 2008. A novel integrated SET based inverter for nano power electronic applications. Am. J. Eng. Applied Sci., 1: 219-222. DOI: 10.3844/ajeassp.2008.219.222

Mohan, K.S.R., P. Jayabalan and A. Rajaraman, 2012. Properties of fly ash based coconut fiber composite. Am. J. Eng. Applied Sci., 5: 29-34.

DOI: 10.3844/ajeassp.2012.29.34

Momani, M.A., T.A. Al Smadi, FM. Al Taweel and K.A. Ghaidan, 2011. GPS ionospheric total electron content and scintillation measurements during the October 2003 magnetic storm. Am. J. Eng. Applied Sci., 4: 301-306. DOI: 10.3844/ajeassp.2011.301.306

Nachiengtai, T., W. Chim-Oye, S. Teachavorasinskun and W. Sa-Ngiamvibool, 2008. Identification of shear band using elastic shear wave propagation. Am. J. Eng. Applied Sci., 1: 188-191.

DOI: 10.3844/ajeassp.2008.188.191

Nahas, R. and S.P. Kozaitis, 2014. Metric for the fusion of synthetic and real imagery from multimodal sensors. Am. J. Eng. Applied Sci., 7: 355-362.

DOI: 10.3844/ajeassp.2014.355.362

Nandhakumar, S., V. Selladurai and S. Sekar, 2009. Numerical investigation of an industrial robot arm control problem using haar wavelet series. Am. J. Eng. Applied Sci., 2: 584-589.

DOI: 10.3844/ajeassp.2009.584.589

Netburn, D., 2018. Mars could have enough molecular oxygen to support life and scientists figured out where to find it Nature. Los Angeles Times.

Ng, K.C., M.Z. Yusoff, K. Munisamy, H. Hasini and N.H. Shuaib, 2008. Time-marching method for computations of high-speed compressible flow on structured and unstructured grid. Am. J. Eng. Applied Sci., 1: 89-94.

DOI: 10.3844/ajeassp.2008.89.94
Odeh, S., R. Faqeh, L. Abu Eid and N. Shamasneh, 2009. Vision-based obstacle avoidance of mobile robot using quantized spatial model. Am. J. Eng. Applied Sci., 2: 611-619.

DOI: 10.3844/ajeassp.2009.611.619

Opafunso, Z.O., I.I. Ozigis and I.A. Adetunde, 2009. Pneumatic and hydraulic systems in coal fluidized bed combustor. Am. J. Eng. Applied Sci., 2: 88-95. DOI: 10.3844/ajeassp.2009.88.95

Pannirselvam, N., P.N. Raghunath and K. Suguna, 2008. Neural network for performance of glass fibre reinforced polymer plated RC beams. Am. J. Eng. Applied Sci., 1: 82-88. DOI: 10.3844 /ajeassp.2008.82.88

Pattanasethanon, S., 2010. The solar tracking system by using digital solar position sensor. Am. J. Eng. Applied Sci., 3: 678-682. DOI: 10.3844/ajeassp.2010.678.682

Petrescu, R.V. and F.I. Petrescu, 2013a. Lockheed Martin. 1st Edn., BoD-Books on Demand, ISBN-10: 3848230739, pp: 114.

Petrescu, R.V. and F.I. Petrescu, 2013b. Northrop. 1st Edn., CreateSpace, pp: 96.

Petrescu, R.V. and F.I. Petrescu, 2013c. The Aviation History or New Aircraft I Color. 1st Edn., CreateSpace, pp: 292.

Petrescu, F.I. and R.V. Petrescu, 2012. New Aircraft II. 1st Edn., Books On Demand, pp: 138.

Petrescu, F.I. and R.V. Petrescu, 2011. Memories about Flight. 1st Edn., CreateSpace, pp: 652.

Petrescu, F.I.T., 2018. About the nuclear particles' structure and dimensions. Comp. Part. Mech. DOI: $10.1007 / \mathrm{s} 40571-018-0206-7$

Petrescu, F.I.T., 2015a. Geometrical synthesis of the distribution mechanisms. Am. J. Eng. Applied Sci., 8: 63-81. DOI: 10.3844/ajeassp.2015.63.81

Petrescu, F.I.T., 2015b. Machine motion equations at the internal combustion heat engines. Am. J. Eng. Applied Sci., 8: 127-137.

DOI: $10.3844 /$ ajeassp.2015.127.137

Petrescu, F.I.T., 2012. Cold nuclear fusion. Plasma Phys. Fusion Technol., 44: 100-100.

Petrescu, R.V., R. Aversa, A. Apicella, S. Li and G. Chen et al., 2016a. Something about electron dimension. Am. J. Applied Sci., 13: 1272-1276.

Petrescu, F.I.T., A. Apicella, R. Aversa, R.V. Petrescu and J.K. Calautit et al., 2016b. Something about the mechanical moment of inertia. Am. J. Applied Sci., 13: $1085-1090$.

Petrescu, F.I.T., A. Apicella, R.V. Petrescu, S.P. Kozaitis and R.B. Bucinell et al., 2016c. Environmental protection through nuclear energy. Am. J. Applied Sci., 13: 941-946.

Petrescu, R.V., R. Aversa, B. Akash, F. Berto and A. Apicella et al., 2017a. Forces of a 3R robot. J. Mechatron. Robot., 1: 1-14. DOI: $10.3844 / j m r s p .2017 .1 .14$ 
Petrescu, R.V., R. Aversa, B. Akash, F. Berto and A. Apicella et al., 2017b. Direct geometry and cinematic to the MP-3R systems. J. Mechatron. Robot., 1: 15-23. DOI: 10.3844/jmrsp.2017.15.23

Petrescu, R.V., R. Aversa, B. Akash, F. Berto and A. Apicella et al., 2017c. Dynamic elements at MP3R. J. Mechatron. Robot., 1: 24-37. DOI: 10.3844/jmrsp.2017.24.37

Petrescu, R.V., R. Aversa, B. Akash, F. Berto and A. Apicella et al., 2017d. Geometry and direct kinematics to MP3R with $4 \times 4$ operators. J. Mechatron. Robot., 1: 38-46. DOI: 10.3844/jmrsp.2017.38.46

Petrescu, R.V., R. Aversa, A. Apicella, M.M. Mirsayar and S. Kozaitis et al., 2017e. Current stage in the field of mechanisms with gears and rods. J. Mechatron. Robot., 1: 47-57. DOI: 10.3844/jmrsp.2017.47.57

Petrescu, R.V., R. Aversa, A. Apicella, M.M. Mirsayar and S. Kozaitis et al., 2017f. Geometry and inverse kinematic at the MP3R mobile systems. J. Mechatron. Robot., 1: 58-65. DOI: 10.3844/jmrsp.2017.58.65

Petrescu, R.V., R. Aversa, A. Apicella, M.M. Mirsayar and S. Kozaitis et al., 2017g. Synthesis of optimal trajectories with functions control at the level of the kinematic drive couplings. J. Mechatron. Robot., 1: 66-74. DOI: 10.3844/jmrsp.2017.66.74

Petrescu, R.V., R. Aversa, A. Apicella, M.M. Mirsayar and S. Kozaitis et al., 2017h. The inverse kinematics of the plane system 2-3 in a mechatronic MP2R system, by a trigonometric method. J. Mechatron. Robot., 1: 75-87. DOI: 10.3844/jmrsp.2017.75.87

Petrescu, R.V., R. Aversa, A. Apicella, M.M. Mirsayar and S. Kozaitis et al., 2017i. Serial, anthropomorphic, spatial, mechatronic systems can be studied more simply in a plan. J. Mechatron. Robot., 1: 88-97. DOI: 10.3844/jmrsp.2017.88.97

Petrescu, R.V., R. Aversa, A. Apicella, M.M. Mirsayar and S. Kozaitis et al., 2017j. Analysis and synthesis of mechanisms with bars and gears used in robots and manipulators. J. Mechatron. Robot., 1: 98-108. DOI: $10.3844 /$ jmrsp.2017.98.108

Petrescu, R.V., R. Aversa, A. Apicella, M.M. Mirsayar and S. Kozaitis et al., 2017k. Speeds and accelerations in direct kinematics to the MP3R systems. J. Mechatron. Robot., 1: 109-117. DOI: 10.3844/jmrsp.2017.109.117

Petrescu, R.V., R. Aversa, A. Apicella, M.M. Mirsayar and S. Kozaitis et al., 20171. Geometry and determining the positions of a plan transporter manipulator. J. Mechatron. Robot., 1: 118-126.

DOI: $10.3844 /$ jmrsp.2017.118.126

Petrescu, R.V., R. Aversa, A. Apicella and F.I.T. Petrescu, 2018a. Total Static Balancing and Kinetostatics of the 3R Base Cinematic Chain. J. Mechatron. Robot., 2: 1-13.

DOI: $10.3844 / j m r s p .2018 .1 .13$
Petrescu, R.V., R. Aversa, A. Apicella and F.I.T. Petrescu, 2018b. Switching from Flat to Spatial Motion to 3R Mechatronic Systems. J. Mechatron. Robot., 2: 14-22. DOI: 10.3844/jmrsp.2018.14.22

Petrescu, R.V., R. Aversa, A. Apicella and F.I.T. Petrescu, 2018c. The dynamics of the planar cinematic balanced chain at the plan module 3R. J. Mechatron. Robot., 2: 23-34. DOI: 10.3844/jmrsp.2018.23.34

Petrescu, R.V., R. Aversa, A. Apicella and F.I.T. Petrescu, 2018d. Dynamic Kinematics of the Plan Balanced Chain at the Planar Module 3R. J. Mechatron. Robot., 2: 35-44. DOI: 10.3844/jmrsp.2018.35.44

Petrescu, F.I.T. and J.K. Calautit, 2016a. About nano fusion and dynamic fusion. Am. J. Applied Sci., 13: 261-266.

Petrescu, F.I.T. and J.K. Calautit, 2016b. About the light dimensions. Am. J. Applied Sci., 13: 321-325.

Pourmahmoud, N., 2008. Rarefied gas flow modeling inside rotating circular cylinder. Am. J. Eng. Applied Sci., 1: 62-65. DOI: 10.3844/ajeassp.2008.62.65

Qutbodin, K., 2010. Merging autopilot/flight control and navigation-flight management systems. Am. J. Eng. Applied Sci., 3: 629-630.

DOI: 10.3844/ajeassp.2010.629.630

Rajbhandari, S., Z. Ghassemlooy and M. Angelova, 2011. The performance of a dual header pulse interval modulation in the presence of artificial light interferences in an indoor optical wireless communications channel with wavelet denoising. Am. J. Eng. Applied Sci., 4: 513-519. DOI: 10.3844 /ajeassp.2011.513.519

Raptis, K.G., G.A. Papadopoulos, T.N. Costopoulos and A.D. Tsolakis, 2011. Experimental study of load sharing in roller-bearing contact by caustics and photoelasticity. Am. J. Eng. Applied Sci., 4: 294-300. DOI: 10.3844/ajeassp.2011.294.300

Semin, A.R. Ismail and R.A. Bakar, 2009a. Combustion temperature effect of diesel engine convert to compressed natural gas engine. Am. J. Eng. Applied Sci., 2: 212-216.

DOI: 10.3844/ajeassp.2009.212.216

Semin, A.R. Ismail and R.A. Bakar, 2009b. Effect of diesel engine converted to sequential port injection compressed natural gas engine on the cylinder pressure Vs crank angle in variation engine speeds. Am. J. Eng. Applied Sci., 2: 154-159. DOI: 10.3844/ajeassp.2009.154.159

Semin S., A.R. Ismail and R.A. Bakar, 2009c. Diesel engine convert to port injection $\mathrm{CNG}$ engine using gaseous injector nozzle multi holes geometries improvement: A review. Am. J. Eng. Applied Sci., 2: 268-278. DOI: 10.3844/ajeassp.2009.268.278

Semin and R.A. Bakar, 2008. A technical review of compressed natural gas as an alternative fuel for internal combustion engines. Am. J. Eng. Applied Sci., 1: 302-311.

DOI: 10.3844/ajeassp.2008.302.311 
Taher, S.A., R. Hematti and M. Nemati, 2008 Comparison of different control strategies in GAbased optimized UPFC controller in electric power systems. Am. J. Eng. Applied Sci., 1: 45-52.

DOI: 10.3844 /ajeassp.2008.45.52

Theansuwan, W. and K. Triratanasirichai, 2011. The biodiesel production from roast Thai sausage oil by transesterification reaction. Am. J. Eng. Applied Sci., 4: 130-132.

DOI: 10.3844/ajeassp.2011.130.132

Thongwan, T., A. Kangrang and S. Homwuttiwong, 2011. An estimation of rainfall using fuzzy setgenetic algorithms model. Am. J. Eng. Applied Sci., 4: 77-81. DOI: 10.3844/ajeassp.2011.77.81

Tourab, W., A. Babouri and M. Nemamcha, 2011. Experimental study of electromagnetic environment in the vicinity of high voltage lines. Am. J. Eng. Applied Sci., 4: 209-213.

DOI: 10.3844/ajeassp.2011.209.213

Tsolakis, A.D. and K.G. Raptis, 2011. Comparison of maximum gear-tooth operating bending stresses derived from niemann's analytical procedure and the finite element method. Am. J. Eng. Applied Sci., 4: 350-354. DOI: 10.3844/ajeassp.2011.350.354

Zhao, B., 2013. Identification of multi-cracks in the gate rotor shaft based on the wavelet finite element method. Am. J. Eng. Applied Sci., 6: 309-319.

DOI: 10.3844/ajeassp.2013.309.319
Zotos, I.S. and T.N. Costopoulos, 2009. On the use of rolling element bearings' models in precision maintenance. Am. J. Eng. Applied Sci., 2: 344-352. DOI: 10.3844/ajeassp.2009.344.352

Zulkifli, R., K. Sopian, S. Abdullah and M.S. Takriff, 2008. Effect of pulsating circular hot air jet frequencies on local and average nusselt number. Am. J. Eng. Applied Sci., 1: 57-61.

DOI: 10.3844/ajeassp.2008.57.61

Zulkifli, R., K. Sopian, S. Abdullah and M.S. Takriff, 2009. Experimental study of flow structures of circular pulsating air jet. Am. J. Eng. Applied Sci., 2: 171-175.

DOI: 10.3844/ajeassp.2009.171.175

\section{Figure Sources}

Fig. 1: Source: https://phys.org/news/2018-10-marsoxygen-life.html

Fig. 2:

Source: http://storage0.dms.mpinteractiv.ro/media/1/186/15786/1 4762945/5/1920.jpg?height $=312 \&$ width $=600$ 